\title{
SEKOLAH RAMAH ANAK TERHADAP PENGEMBANGAN SOSIO- EMOSIONAL ANAK DI SD NEGERI NGUPASAN YOGYAKARTA
}

\author{
Muhammad Majdi ${ }^{1}$, Ahmad Shofiyuddin Ichsan ${ }^{2}$ \\ ISekolah Tinggi Ilmu Al-Quran (STIQ) Amuntai, Kalimantan Selatan \\ Institut Ilmu Al Qur'an An Nur Yogyakarta \\ *Email: ahmad.shofiyuddin.ichsan@gmail.com
}

\begin{abstract}
School being a source of stress among students seems to be a reality that all circles need to anticipate. As a formal educational institution, school has to have a friendly nature, both friendly to children and friendly to the environment, so that they can have a positive effect on children's socio-emotional development. The purpose of this research is to reveal how the contribution of Child Friendly School (Sekolah Ramah Anak/SRA) in the socio-emotional development of children at SD Negeri Ngupasan Yogyakarta. This research is qualitative and the research method used is descriptive-inductive method. Data are collected and described through in-depth observations and interviews, while the data analysis method applied is Cresswell's qualitative data. The results show that SRA has a contribution in the socio-emotional development of children at SD Negeri Ngupasan Yogyakarta. The stages of SRA program include: 1) Anti-violence policies; 2). Implementation of the curriculum; 3 Educators and education personnel trained in child rights; 4). Facilities and infrastructure; 5). Student participation; and 6) Parental participation. The contribution obtained from the implementation of $S R A$ program in socio-emotional development is that students could respect others, more able to control emotions, responsive, bound by parental figures, care, imitate their friends, play games that use rules and create them, following an event, confident, tolerant, cooperative and responsible, and tend to spend time with friends.
\end{abstract}

Keywords: child friendly school, child socio-emotional development, elementary school

\section{PENDAHULUAN}

Kesadaran bahwa sekolah menjadi sumber stres di kalangan siswa agaknya juga terjadi di Indonesia. Stres sekolah sebagai ketegangan emosional yang muncul dari peristiwa-peristiwa kehidupan di sekolah dan perasaan terancamnya keselamatan atau harga diri siswa, sehingga memunculkan reaksi-reaksi fisik, psikologis, dan tingkah laku yang berdampak pada penyesuaian psikologis dan prestasi akademis (Desmita, 2010:291). Stres juga merupakan suatu kondisi yang 
disebabkan ketidaksesuaian antara situasi yang diharapkan dan keadaan psikologis, biologis, atau sistem sosial dari masing-masing individu (Barseli, dkk., 2017:144). Maka dari itu, stres merupakan situasi tekanan emosional individu terhadap ketidaksesuaian antara situasi yang diinginkan dan yang diharapkan, sehingga mengancam psikologis karena melebihi kemampuan untuk mengatasinya. Sekolah dalam konteks ini harus senantiasa menciptakan suasana nyaman dan kondusif, agar warga sekolah (khususnya siswa) dapat mengekspresikan segala potensinya (Kristanto, dkk., 2011:74). Maka dari itu, Desmita mengidentifikasi ada empat tuntutan sekolah yang disesuaikan permasalahan yang berkembang selama ini, yaitu tuntutan fisik, tuntutan tugas, tuntutan peran, dan tuntutan interpersonal. Di titik ini, sebagai lembaga pendidikan formal, sekolah seharusnya memiliki sifat yang ramah, baik itu ramah kepada anak maupun ramah terhadap lingkungan, agar dapat berpengaruh positif atas perkembangan sosio-emosional anak.

Terkait penelitian terdahuluan yang dilakukan oleh Carter (2016) tentang Pendekatan Sosio-Emosional berbasis alam, Debora menguraikan pendekatan sosial-emosional berbasis alam untuk mendukung perkembangan holistik anak muda yang dapat diterapkan dalam berbagai pengaturan anak usia dini dari TK hutan dan prasekolah berbasis alam ke program anak usia dini berbasis pusat yang lebih tradisional. Kerangka Pengembangan Pendidikan Sosial-Emosional dan Lingkungan (SEED) memadukan pendidikan anak usia dini, pendidikan lingkungan, dan pengembangan sosial-emosional melalui integrasi rekomendasi praktik terbaik dari Asosiasi Nasional untuk Pendidikan Standar Program Anak Usia Dini, Program Pendidikan Lingkungan Anak Usia Dini, dan Model Piramida untuk mendukung kompetensi emosional sosial pada bayi dan anak kecil. SEED Framework menyediakan program-program anak usia dini sebagai panduan untuk mengintegrasikan dan menanamkan pendekatan sosio-emosional berbasis alam di seluruh aspek program mereka (Carter, 2016).

Perkembangan sosio-emosional adalah suatu proses pengembangan kemampuan anak dalam menyesuaikan dirinya untuk bersosialisasi, baik dalam arti sempit maupun dalam arti luas (Soetjiningsih, 2014:264). Menurut Elizabeth B Hurlock, pada masa kanak-kanak, ada dorongan yang kuat bagi anak untuk bergaul dengan orang lain dan ingin diterima oleh orang lain. Jika kebutuhan ini tidak dipenuhi, anak-anak tidak akan bahagia, jika kebutuhan ini dipenuhi, mereka akan puas dan bahagia (Hurlock, 1987:250). Maka dari itu, upaya dalam meningkatkan perkembangan sosio-emosional anak dapat dilihat dalam bukunya Carolyn Meggitt dengan rentan usia 5-8 tahun. Buku tersebut dijelaskan bahwa ketika usia anak 5-8 tahun, maka seharusnya: 1) Membantu anak menjelajahi dunianya dengan membawanya ke muesum, taman kota, atau galer seni, 2) Menyediakan dorongan semangat yang realistis anak-anak dari segala umur sehingga ada feedback yang positif yang disukainya, 3) Memberikan banyak 
kesempatan untuk bermain secara bebas, sehingga anak yang memegang kontrol untuk menentukan aktivitasnyap ada hari itu, 4) Mendorong anak-anak untuk melakukan aktivitas yang non stereotype, misalnya anak perempuan tidak apa-apa jika menyukai sepak bola, anak laki-laki boleh saja menyukai kegiatan menjahit, 5) Meningkatkan sopan santun saat makan dengan menetapkan beberapa aturan sederhana. Hal ini misalnya, tidak boleh ada mainan di meja makan, bersikap sopan ketika makan di rumah orang lain meskipun makanannya tidak disukai, dan seterusnya, 6) Tetap tegas dan konsisten dengan aturan waktu tidur anakanak dengan kisaran usia ini membutuhkan waktu tidur sebanyak 9 hingga 11 jam perharinya (Meggitt, 2012:152-153).

Tidak hanya itu, terdapat beberapa upaya meningkatkan perkembangan sosio-emosional anak usia 8-12 tahun, antara lain: 1) Menjaga hubungan keluarga yang hangat dan terbuka terhadap anak. Hal ini dapat mendorong anak untuk bercerita kepada orangtua jika mereka mengalami masalah, 2) Meluangkan waktu bersama sebagai keluarga. Hal ini misalnya, makan bersama, atau berjalan-jalan bersama ke taman, dan seterusnya, 3) Memberikan mereka lebih tanggung jawab di rumah dan memberikan mereka dukungan serta semangat dalam mengerjakan tugas sekolah, 4) Menetapkan kemudian mempertahankan batasan yang jelas terkait perilaku anak, 5) Membantu anak untuk mengembangkan daya tahannya melalui pengajaran berbagai macam nilai dan keterampilan yang penting bagi kehidupannya di masa depan (Menggitt, 2012:168-169).

KPAI (Komisi Perlindungan Anak Indonesia) mengartikan Sekolah Ramah Anak adalah sekolah yang secara sadar berupaya kuat untuk menjamin dan memenuhi hak-hak dan perlindungan anak dalam setiap aspek kehidupan secara terencana dan bertanggung jawab (Sholih \& Humaidi, 2016:174). Tidak hanya itu, Peraturan Menteri Negara Pemberdayaan Perempuan dan Perlindungan Anak Republik Indonesia Nomor 8 Tahun 2014 pasal 13 menyebutkan Sekolah Ramah Anak yang selanjutnya disingkat SRA adalah satuan pendidikan formal, nonformal, dan informal yang aman, bersih dan sehat, peduli dan berbudaya lingkungan hidup, mampu menjamin, memenuhi, menghargai hak-hak anak dan perlindungan anak dari kekerasan, diskriminasi, dan perlakuan salah lainnya serta mendukung partisipasi anak terutama dalam perencanaan, kebijakan, pembelajaran, pengawasan, dan mekanisme pengaduan terkait pemenuhan hak dan perlindungan anak di pendidikan (Permen PPA RI, 2014).

Prinsip-Prinsip Sekolah Ramah Anak seperti yang ditulis dalam buku Asrorun Ni'am Sholeh dan Lutfi Humaidi dengan judul "Panduan Sekolah \& Madrasah Ramah Anak" menyebutkan bahwa Sekolah Ramah Anak harus meliputi sebagaimana berikut: 1) Tanpa Kekerasan, 2) Tanpa Diskriminasi, 3) Kepentingan terbaik bagi anak dan hak tumbuh dan berkembang, 4) Penghargaan terhadap pendapat anak (Sholih \& Humaidi, 2014:174). Adapun indikator Sekolah Ramah Anak memiliki enam komponen indicator penting, yaitu: 1) Kebijakan 
Sekolah Ramah Anak (SRA), 2) Pelaksanaan kurikulum, 3) Pendidik dan tenaga kependidikan terlatih hak- hak anak, 4) Sarana dan prasarana Sekolah Ramah Anak (SRA), 5) Partisipasi anak, dan 6) Partisipasi orang tua, lembaga masyarakat, dunia usaha, pemangku kepentingan lainnya, dan alumni (Permen PPA RI, 2014).

Penelitian terkait Sekolah Ramah Anak sendiri sudah banyak yang membahas, seperti AT. Hasibuan (2019), Alfina (2020), Nuraeni, dkk. (2019), Yosada, dkk. (2019), Indraswati, dkk. (2020), dan ada beberapa peneliti lainnya, tetapi sepanjang penelusuran pustaka yang peneliti lakukan belum ada penelitian yang secara spesifik yang membahas tentang keterkaitan Sekolah Ramah Anak terhadap pengembangan sosio-emosional anak usia Sekolah Dasar. Berdasarkan hal tersebut, penelitian ini penting untuk dikaji lebih mendalam, dalam rangka menganalisis program Sekolah Ramah Anak (SRA) terhadap pengembangan sosio-emosional anak di SD Negeri Ngupasan Yogyakarta. Pemilihan objek penelitian di SD Negeri Ngupasan karena di sekolah ini telah lama menerapkan program SRA dan hasil implementasi program tersebut telah diakui oleh Dinas Pendidikan setempat, sehingga hal itu sangat menarik untuk diteliti dan dikaji dengan harapan hasil penelitian ini bisa dijadikan salah satu kontribusi penting dalam konteks memperbaiki kualitas pendidikan nasional di Indonesia.

\section{METODE PENELITIAN}

Penelitian bersifat kualitatif, yaitu mendeskripsikan keadaan yang terjadi di lapangan, sedangkan metode penelitian ini menggunakan metode deskriptif dan bersifat induktif dengan membiarkan masalah-masalah berkembang dari data. Data dikumpulkan dan dideskripsi dari hasil observasi dan wawancara yang mendalam (Sukmadinata, 2015:60). Subjek dalam penelitian ini adalah: 1) Kepala Sekolah; 2) Sekretaris dan koordinator TIM program Sekolah Ramah Anak; 3) Guru; 4) Orang tua siswa; dan 5) Beberapa siswa SD Negeri Ngupasan Yogyakarta. Penelitian ini fokus kepada pengembangan sosio-emosional anak pada siswa SD Negeri Ngupasan Yogyakarta.

Metode analisis data yang diterapkan dalam penelitian ini adalah data kualitatif Cresswell dengan mengikuti prosedur sebagai berikut: 1). Mengatur, mengelompokkan, mengorganisasi, dan menyiapkan data yang dianalisa, 2). Membaca, memahami, dan melihat semua data terkait tentang Sekolah Ramah Anak dalam pengembangan sosio-emosional anak, 4). Korelasi antar tema terkait, dan 5). Memberikan interpretasi tentang tema dalam penelitian (Sugiyono, 2017:163-164).

\section{HASIL DAN PEMBAHASAN}

Sekolah Ramah Anak adalah sekolah yang menjunjung tinggi hak anak termasuk penyandang disabilitas. SD Negeri Ngupasan Yogyakarta belum 
menjadi sekolah inklusi. Gedung bangunan sekolah ini belum mendukung untuk penyandang disabilitas. Tetapi mereka tidak serta merta menolak program itu, tetapi memberikan masukan atau pandangan-pandangan terkait hal itu. Tidak hanya itu, sekolah ini juga bekerjasama dengan SLB Negeri II Yogyakarta untuk menghadirkan psikolog untuk assessment.

Indikator Sekolah Ramah Anak (SRA) yang dilihat dalam konteks SD Negeri Kupasan Yogyakarta dapat meliputi 6 (enam) komponen penting, yaitu: 1) Kebijakan Sekolah Ramah Anak (SRA), 2). Pelaksanaan kurikulum, 3). Pendidik dan tenaga kependidikan terlatih hak-hak anak, 4). Sarana dan prasarana Sekolah Ramah Anak (SRA), 5). Partisipasi anak, dan 6). Partisipasi orang tua. Setiap indikator tersebut dideskripsikan dan dianalisis untuk melihat kontribusinya dalam pengembangan sosio-emosional anak usia dasar di SD Negeri Ngupasan Yogyakarta. Dari proses implementasi program ini, diharapkan memberikan kontribusi yang positif dari sosio-emosional siswa, khususnya di sekolah itu.

\section{Kebijakan Sekolah Ramah Anak}

Pelaksanaan Sekolah Ramah Anak (SRA) di SD Negeri Ngupasan Yogyakarta didasarkan pada Pasal 4, Peraturan Menteri Negara Pemberdayaan Perempuan dan Perlindungan Anak Republik Indonesia Nomor 8 Tahun 2014 tentang Kebijakan Sekolah Ramah Anak. Pelaksanaannya didasarkan pada indikator-indikator yang telah ditetapkan di dalam kebijakan Sekolah Ramah Anak. Pelaksanaan pendidikan ramah anak di SD Negeri Ngupasan Yogyakarta dapat dirinci dalam indikator-indikator yang telah dipenuhi.

Sekolah Ramah Anak (SRA) adalah sekolah yang melaksanakan pendidikan anti kekerasan dan pendidikan inklusi. Pendidikan anti kekerasan meliputi adanya larangan terhadap tindak kekerasan dan diskriminasi antar siswa (bullying), antar pendidik dan pegawai sekolah. SD Negeri Ngupasan Yogyakarta tidak memiliki catatan sejarah mengenai tindak kekerasan yang terjadi di sekolah tersebut. Kepala sekolah SD Negeri Ngupasan Yogyakarta dan guru-guru di sekolah diberikan sosialisasi bahwa sekolah yang ramah terhadap anak adalah tidak melakukan kekerasan terhadap siswa dan memberikan rasa aman dan nyaman ke siswa, sehingga label dari Sekolah Ramah Anak tidak dipandang sebatas label saja melainkan memang ada dampak dan kontribusi yang positif ke siswa. Peneliti juga menanyakan kepada orang tua siswa menurut Ibu Tari Barata dan Bapak Gusmianto bahwa sebuah fakta di Sekolah ini sesudah menerapkan program Sekolah Ramah Anak dan ramah lingkungan telah berdampak positif kepada siswa.

Perkembangan sosio-emosional anak usia dasar umur 7-8 tahun dari data di atas dapat dianalisis perkembangan sosio-emosional anak yaitu menginternalisasi aturan sosial dalam budayanya yang terkandung pada nilai moralnya bahwa anak dapat menghargai orang lain dalam hal ini adalah teman sebayanya. Sedangkan perkembangan sosio-emosional anak umur 8-9 tahun kejadian di atas dapat 
dikelompokkan di bagian indikator anak dalam konteks arumentatif dan suka mengatur, namun bisa responsif serta murah hati sekaligus. Sesuai dengan penjelasan Carolyn Meggitt bahwa upaya dalam meningkatkan perkembangan sosio-emosional anak, yaitu membantu anak untuk mengembangkan daya tahannya melalui mengajarkan berbagai macam nilai. Hal ini seperti kemampuan anak untuk menghargai diri dan orang lain (Meggitt: 2012).

Komitmen sekolah lainnya yaitu membuat kebijakan secara tertulis dan itu telah dijadikan sebagai tata tertib kelas dan ditempel di setiap kelas. Jika ada siswa yang melanggar, nanti siswa akan mendapatkan poin-poin tertentu. Hal ini sebagai upaya upaya meningkatkan perkembangan sosio-emosional anak sebagai penetapan dan pembatasan yang jelas mengenai perilaku anak. Dalam perkembangan sosio-emosional anak usia dasar, indikator umur 7-8 tahun jika disesuaikan dengan kegiatan di atas menggambarkan bagaimana indikator dapat menanggapi setiap penjelasan dengan positif. Terbukti anak dengan adanya program Sekolah Ramah Anak, pihak sekolah mengupayakan untuk menjadi sekolah yang ramah buat anak dalam segala hal, termasuk memberikan shock therapy tersebut.

Komitmen SD Negeri Ngupasan Yogyakarta sebagai Sekolah Ramah Anak lainnya adalah memberi rasa aman dan nyaman untuk siswa. Dalam hal ini, sekolah mengajak orang tua untuk mengantar jemput anak ke sekolah, dengan alasan agar keamanan anak terjamin dan meminimalisir siswa untuk tidak masuk sekolah dengan alasan apapun. Sekolah Ramah Anak memberi sosialisasi kepada warga sekolahnya untuk saling menjaga agar sama-sama mendapatkan rasa aman dan nyaman. Dalam perkembangan sosio-emosional anak dalam indikatornya bahwa anak cenderung terikat pada figur-figur orang tua. Dari penjelasan siswa, peneliti mendapatkan informasi bahwa ada dampak tersendiri dari kegiatan antar jemput oleh orang tua, yaitu siswa lebih percaya diri dan mandiri di sekolah. Hal ini sesuai indikator perkembangan sosio-emosional anak karena mendapat dukungan langsung dari orang tuanya ketika berangkat ke sekolah.

Selanjutnya, komitmen Sekolah Ramah Anak (SRA) di SD Negeri Ngupasan Yogyakarta ini adalah mewujudkan kawasan tanpa rokok di lingkungan sekolah. Bentuk komitmen sekolah yaitu memiliki rambu-rambu berupa larangan merokok di tempat-tempat umum di sekolah. Jika dikaitkan dengan penjelasan Carolyn Meggitt, upaya dalam meningkatkan perkembangan sosio-emosional anak dalam menyediakan dorongan semangat yang realistis, yaitu adanya komitmen sekolah dengan memiliki aturan yang jelas berupa larangan merokok.

Terkait peduli bencana, SD Negeri Ngupasan Yogyakarta juga ikut berpartisipasi atas bencana alam yang ada di Dunggala dan beberapa daerah lainnya. Hasil wawancara dengan Ibu Dwi Yuliana bahwa SD Negeri Ngupasan Yogyakarta dalam kejadian bencana alam juga ikut berpartisipasi dalam wujud 
sumbangan uang dan pakaian bekas untuk semua warga sekolah. Sekolah bekerjasama dengan paguyuban siswa dan seluruh warga sekolah berhasil berbagai mengumpulkan dana. Hal ini juga dimaksudkan pihak sekolah memberikan tauladan kepada siswa untuk menanamkan nilai sosial saling berbagi dan peduli kepada sesama. Perkembangan sosio-emosional anak sesuai dengan indikator umur 7-8 tahun bahwa anak memiliki pemahaman sosial yang lebih luas dapat merasa terganggu dengan program pemberitaan yang menampilkan kekerasan atau bencana alam. Selain itu, bentuk kepedulian lain yang telah menjadi budaya di sekolah ini adalah adanya kepedulian sesama pada teman sebayanya ketika ada salah satu teman yang sakit (Yuliana, 2019).

\section{Pelaksanaan Kurikulum}

SD Negeri Ngupasan Yogyakarta sebagai Sekolah Ramah Anak (SRA) memiliki perencanaan pendidikan yang berbasis hak anak yang terintegrasi dengan Rencana Pelaksanaan Pembelajaran (RPP) yang ramah terhadap anak. Perencanaan pendidikan ini artinya RPP tidak mengandung unsur-unsur kekerasan, pornografi, dan terorisme di dalamnya. Guru di SD Negeri Ngupasan Yogyakarta, menurut ibu Menik sebagai wali kelas 4, telah merancang Rencana Pelaksanaan Pembelajaran (RPP) yang ramah terhadap anak, yang di dalamnya tidak mengandung kekerasan. Melaksanakan pembelajaran yang ramah dan terkait materi ramah anak disesuaikan dengan materi yang sedang dibahas ketika pembelajaran di setiap tema.

Selain itu, upaya-upaya lain dari sekolah dalam menciptakan rasa aman dan nyaman siswa melalui SRA ini adalah diadakannya jadwal piket guru untuk menyambut kedatangan anak di sekolah yang diantar oleh orang tuanya. Hal ini sesuai dengan upaya meningkatkan perkembangan sosio-emosional anak pada konteks "meningkatkan sopan santun", "menjaga hubungan yang hangat dan terbuka" dan "meluangkan waktu bersama". Dalam meningkatkan sopan santun bahwa sebagai Sekolah Ramah Anak, pihak sekolah khususnya guru menjadi Role Model bagi siswanya. Jadi, upaya sekolah dalam menciptakan rasa aman dan nyaman siswa dengan selalu menciptakan suasana yang kondusif. Sedangkan pada konteks "meluangkan waktu bersama" dapat dilihat pada kegiatan piket pagi dalam meluangkan waktu untuk menyambut kedatangan anak di depan sekolah dalam memulai hari. Dengan begitu, anak merasa aman dan nyaman ketika berada di sekolah, khususnya waktu orang tua mengantarnya.

Selain kegiatan pembelajaran dengan RPP ramah anak, juga dapat dilihat dari proses belajar mengajar di kelas dengan ruang kelas yang bersih dan luas, karena sebagian ruangan kelas adalah bangunan cagar budaya dan sebagian lainnya adalah bangunan baru. Maka tidak mengherankan bahwa luas setiap kelas berbeda, tetapi pihak sekolah dapat menyesuaikan dengan mengatasinya dengan menyetarakan antara jumlah siswa dengan luas bangunan kelas. Hasil observasi peneliti bahwa setiap ruang kelas dilengkapi dengan LCD, CCTV dan kipas angin 
untuk menunjang kenyamanan siswa di dalam kelas, sedangkan di luar kelas juga tersedia masing-masing tempat sampah dan setiap sudut sekolah mempunyai tempat cuci tangannya. Misalnya, penggunaan LCD akan berpengaruh kepada semangat anak untuk mengikuti proses pembelajaran dan adanya CCTV agar siswa sadar dan lebih menjaga perilakunya tidak menyimpang dan merugikan orang lain (Ambarsari\&Harun, 2018:15).

Guru SD Negeri Ngupasan Yogyakarta menggunakan media tidak hanya bergantung pada teknologi, tetapi ada inovasi lain yang mereka gunakan untuk menjelaskan sebuah materi. Misalnya, pada materi bencana alam, guru sudah menyiapkan media-media untuk menunjang penjelasannya terhadap bencana alam tersebut, seperti Angin Puting Beliung, Tanah Longsor, Tsunami, dan lainlain. Guru mempunyai miniatur kecil yang dibuat dari bahan bekas menciptakan simulasi Tsunami dan dijelaskan kepada siswa. Selain media tersebut berbentuk 3D, guru juga mengeksplorasi hasil kreasi tersebut dengan membuat daya tarik dan pengalaman langsung yang dirasakan siswa ketika mencobanya. Hal ini terlihat bagaimana teknologi informasi menjadi faktor penting untuk digunakan guru dalam rangka meningkatkan cara berinteraksi secara sosial antara manusia dengan yang lainnya (Ichsan, 2019:2).

Selain itu, permainan edukatif di SD Negeri Ngupasan Yogyakarta ini seperti permainan dakon dan permainan lingkaran-lingkaran dari Thailand dan Jepang. Ada juga permainan dari hasil buatan sendiri dari sekolah. Perkembangan sosio-emosional anak usia dasar diketahui bahwa indikator umur 7-8 tahun, anak dapat memainkan permainan yang memakai aturan. SD Negeri Ngupasan Yogyakarta memiliki beberapa jenis permainan dari lokal yang diambil dari lingkungan sekitar sampai permainan internasional dan permainan lainnya yang berhubungan dengan ekstrakurikuler PRB. Jenis-jenis permainan tersebut juga ada yang memerlukan bimbingan guru dan ada juga tidak. Tidak hanya itu, cara memainkannya juga bisa dengan sendiri ataupun berkelompok. Dalam konteks ini, lingkungan sekitar merupakan salah satu sumber belajar yang bisa digunakan dalam proses pembelajaran (Chrislando, 2019:1).

Hal ini sejalan dalam penjelasan Christiana Hari Soetjiningsih bahwa bermain juga merupakan salah satu cara bagi anak untuk mengasah kepekaannya melalui kelompok pergaulannya. Kegiatan ini memberi kesempatan pada anak untuk belajar berbagi. Pada saat siswa kelas atas di sekolah dasar, siswa akan memperoleh kepuasan yang lebih besar jika bermain dengan teman yang seusia, berminat sama, dan dari jenis kelamin yang sama (Soetjiningsih, 2014). Hal ini sesuai dengan upaya meningkatkan perkembangan sosio-emosional anak sebagaimana penjelasan Carolyn Meggitt pada poin "memberikan banyak kesempatan untuk bermain secara bebas". Untuk menciptakan keadaan Sekolah Ramah Anak, SD Negeri Ngupasan Yogyakarta menyediakan permainan untuk 
siswanya, bentuk permainan tersebut berupa permainan lokal dan mainan dari luar negeri.

SD Negeri Ngupasan Yogyakarta memiliki berbagai macam ekstrakurikuler termasuk di dalamnya ekstrakurikuler Karawitan, musik, batik, Pramuka, PRB, Jurnalis, Silat, Taman Pendidikan Al Qur'an (bekerjasama dengan masjid di sekitarnya), dan ekstrakurikuler olahraga. Ekstrkurikuler PRB dan Pramuka salah satu ektrakurikuler penunjang untuk program SRA dan Adiwiyata di sekolah ini. Perkembangan sosio-emosional anak usia dasar, sesuai dengan indikator umur 8-9 tahun bahwa anak bangga terhadap kompetensi diri sendiri, mudah patah semangat, mulai mengidentifikasi aktivitas dan kemampuan tertentu sebagai karakter yang maskulin dan feminim, dan berteman dengan teman yang berjenis sama yang didasarkan pada kesamaan hobi dan yang lainnya.

Selain ektrakurikuler, ada beberapa kegiatan lain yang mendukung untuk pengembangan minat, bakat, dan inovasi serta kreativitas siswa adalah kelas inspirasi dan kelas kreatif. Hasil wawancara diketahui bahwa kegiatan yang diadakan di SD Negeri Ngupasan Yogyakarta pada semester ganjil setelah ulangan sekolah mengundang tokoh atau seorang yang inspiratif di bidangnya. Kegiatan baru ini diadakan dengan mengundang dokter Deo dan pesertanya adalah kelas 1, 2, dan 3. Sedangkan kelas 4, 5, dan 6 mengundang psikolog dengan materi yang diangkat adalah kehidupan perkembangan anak sesuai dengan umur mereka.

Sesuai indikator umur 7-8 tahun dalam perkembangan sosio-emosonal anak usia dasar bahwa anak dapat menginternalisasi aturan sosial dan budayanya, anak juga dapat mengikuti sebuah kejadian dari awal hingga akhir. Kegiatan tersebut memberikan gambaran kepada siswa tentang keterampilan dalam dirinya. Sekolah Ramah Anak memberikan perannya dalam perkembangan sosioemosional anak, yakni menyediakan dorongan realistis dengan mengadakan kelas inspirasi untuk anak dalam rangka mendukung pengembangan minat, bakat, inovasi, dan kreativitas siswa. Kelas Inspirasi memberikan pembelajaran kontekstual kepada siswa, karena siswa secara langsung bertemu dengan tokoh dan ikut merasakan menjadi tokoh tersebut.

\section{Pendidik dan Tenaga Kependidikan Terlatih Hak-Hak Anak}

Lembaga pendidikan yang baik tidak hanya dapat dilihat dari sarana prasarana yang baik, tetapi juga harus ditopang oleh pendidik yang bermutu dan berkualitas (Suryadi, 2002:31)). Kualitas pendidik akan terlihat ketika mereka mampu menciptakan suasana belajar yang disukai siswa, sehingga siswa antusias dalam belajar di kelas. Dalam konteks penelitian ini, setelah keluar SK (Surat Keputusan) dari Wali Kota Yogyakarta tentang Sekolah Ramah Anak (SRA) di SDN Ngupasan Yogyakarta, tidak ada pelatihan khusus terhadap tenaga sekolah, hanya beberapa tenaga saja yang mengikuti sosialisasi di awal. Berhubung Sekolah Ramah Anak (SRA) sangat berhubungan dengan Pengurangan Resiko 
Bencana (PRB), sehingga pembina ekstrakurikuler Pengurangan Resiko Bencana (PRB) sering mendapatkan pelatihan terkait hal tersebut. Di dalam pelatihannya, guru pembina esktrakurikuler Pengurangan Resiko Bencana (PRB) mendapatkan workshop dan penguatan tentang kegiatan ekstrakurikuler sebagai model sekolah unggulan mutu pendidikan.

Adapun seminar atau workshop yang diselenggarakan oleh SDN Ngupasan Yogyakarta terkait program SRA dan hak anak telah beberapa kali dilakukan. Salah satu kegiatannya dilakukan pada tanggal 23 November 2018 tentang sosialisasi ke warga sekolah (termasuk ke orang tua siswa). Tema yang diangkat pada kegiatan tersebut yaitu "Pola Asuh Orang Tua Zaman Now" dengan pemateri dari KPAI (Komisi Perlindungan Anak Indonesia) Yogyakarta.

\section{Sarana dan Prasarana Sekolah Ramah Anak}

Sekolah Ramah Anak memiliki indikator dalam pencapaian sarana prasarana dan memiliki kapasitas ruangan yang sesuai dengan jumlah siswa. Sarana prasarana adalah salah satu kunci dalam mewujudkan Sekolah Ramah Anah, karena dengan adanya hal tersebut akan tercipta suasana pendidikan yang mengedepankan hak-hak anak dalam proses belajar-mengajar (Hasibuan \& Rahmawati, 2019:67).

Hasil dokumentasi profil sekolah SD Negeri Ngupasan Yogyakarta telah memiliki siswa yang banyak 338 siswa. Hasil dari observasi yang dilakukan peneliti terdapat 12 ruang kelas dengan kondisi yang baik dan terang, terdapat meja dan kursi dalam kondisi yang baik, lemari, kipas angin, dan fasilitas $L C D$. Sarana dan prasarana yang ada di sekolah sudah dapat menampung jumlah siswa yang tersebar dari kelas 1-6 meliputi kelas A dan B, dan setiap kelas maksimal diisi oleh 30 siswa. Setiap depan kelas juga terdapat tempat sampah dan tanamantanaman hijau. Artinya, sarana dan prasarana yang ada di SD Negeri Ngupasan Yogyakarta sudah baik dan mencukupi.

Bentuk sosialisasi dari pihak sekolah dalam menyuarakan sekolah yang ramah buat anak adalah ajakan tidak membully satu sama lain, menyebut nama orang tua dengan nama aslinya, dan saling menghargai. Selain ajakan pada saat kegiatan-kegiatan tertentu (khususnya di acara upacara mingguan), pihak sekolah menggunakan tulisan-tulisan yang ditempel di sekolah untuk mengajak siswa agar saling menghargai, di antaranya "Stop Bulliying di Sekolah". Tidak hanya itu, sekolah juga mempunyai media sosialisasi berupa gambar slide yang bisa digunakan guru di kelas untuk menjelaskan larangan Bulliying.

Maka sesuai dengan apa yang dikatakan oleh Carolyn Meggitt upaya dalam meningkatakan perkembangan sosio-emosional anak, yaitu dengan menyediakan dorongan semangat yang realistis. Yang dilakukan sekolah dalam hal ini adalah dalam menyuarakan pendidikan anti-kekerasan, seperti larangan terhadap tindak kekerasan dan diskriminasi antar siswa (bullying), tidak menyebut nama orang tua, dan seterusnya sebagaimana yang telah dijelaskan di atas. 
SD Negeri Ngupasan Yogyakarta sebagai Sekolah Ramah Anak juga memiliki toilet yang terpisah antara siswa laki-laki dan perempuan. Kebutuhan siswa terkait kebersihan toilet sudah dapat dipenuhi di sekolah ini. Terkait kegunaannya, siswa dapat menginternalisasi aturan sosial tersebut dalam budayanya dengan menggunakan toilet laki-laki dan perempuan sesuai aturan yang semestinya. Selain itu, beberapa kamar mandi juga disediakan di sekolah ini. Perkembangan sosio-emosional anak sesuai indikator umur 7-8 tahun bahwa anak dapat menginternalisasi aturan sosial dalam budayanya, sehingga aturan tersebut mampu diterapkan dengan baik.

SD Negeri Ngupasan Yogyakarta juga menyediakan tempat sampah terpilah, yaitu tempat sampah warna hijau untuk sampah daun, tempat sampah warna kuning untuk sampah kertas, dan tempat sampah warna merah untuk sampah plastik. Jumlah tempat sampah cukup memadai hampir di setiap sudut kelas memiliki tempat sampah. Sehingga siswa juga dibiasakan oleh guru dalam memilah sampah agar penggunaannya tepat sasaran. Pada saat penilaian kelas bersih, dapat dilihat kelas yang paham dan belum dalam penggunaan tempat sampah terpilah, sehingga melalui hal tersebut akan ada teguran dari guru bersangkutan atau wali kelasnya. Dalam perkembangan sosio-emosional sesuai indikator umur 7-8 tahun bahwa anak dapat memainkan permainan yang memakai aturan dalam hal ini adalah pada membuang sampah yang terpilah bahwa siswa dapat menjelankannya sesuai dengan aturan. Dari hasil wawancara, hampir mayoritas siswa di sekolah ini telah mengetahui dan memahami fungsi dari setiap tempat sampah.

Dapat dilihat sarana kebutuhan kebersihan siswa telah dipenuhi oleh SD Negeri Ngupasan Yogyakarta. Adapun sarana lainnya adalah tempat cuci tangan. Tempat cuci tangan di SD Negeri Ngupasan Yogyakarta dilengkapi dengan sabun dan terdapat tulisan tata cara mencuci tangan dengan baik dan benar. Pihak sekolah bekerjasama dengan Puskesmas Kecamatan Gondomanan mensosialisasikan cara mencuci tangan dengan baik dan benar untuk siswa pada setiap kelas dengan dipraktekkan langsung dari pihak Puskemas. Dalam konteks ini, perkembangan sosio-emosional anak usia dasar indikator umur 7-8 tahun bahwa anak dapat memainkan permainan yang memakai aturan.

Penggunaan tempat cuci tangan dan cara mencuci tangan dengan baik dan benar telah berjalan sesuai aturan yang berlaku dan sudah dipraktekkan oleh pihak puskesmas. Peneliti menanyakan hal serupa kepada siswa dengan jawaban semua sudah tahu cara mencuci tangan dengan baik dan benar. Adapun pada kegiatan ibadah seperti berwudhu, anak diajarkan oleh guru agamanya untuk berwudhu dengan baik dan benar.

Komitmen lainnya terkait Sekolah Ramah Anak adalah sekolah memperhatikan penyelanggaraan ibadah siswa dengan menjamin, melindungi, dan memenuhi hak siswa untuk menjalankan ibadah sesuai dengan agamanya masing- 
masing. Siswa di SD Negeri Ngupasan Yogyakarta memiliki pemeluk di tiga agama yang berbeda, yaitu agama Islam, Katholik, dan Protestan. Perhatian dalam penyelenggaraan ibadah ini sebagai bentuk penghargaan sekolah terhadap agama siswa yang dianutnya. Pada perkembangan sosio-emosional anak indikatot umur 7-8 tahun bahwa anak dapat menginternalisasi aturan sosial dalam budayanya, yakni terkait toleransi yang ada di sekolahnya tentang menghargai teman lain yang berbeda agama.

Selanjutnya, SD Negeri Ngupasan Yogyakarta memiliki Unit Kesehatan Sekolah (UKS) untuk memenuhi pelayananan kesehatan siswa dan warga sekolah. Peraturan yang ada disebutkan bahwa Sekolah Ramah Anak (SRA) harus memiliki ruang UKS dengan perlengkapan seperti tempat tidur, perlengkapan P3K, alat ukur berat badan dan tinggi badan, karena Kesehatan jasmani dan rohani anak sudah menjadi kewajiban yang harus dipenuhi oleh guru dan orang tua. Kebutuhan jasmani berupa makan, minum, pakaian, dan sebagainya adalah pemenuhan yang harus dilakukan di dalam sekolah. Penggunaan UKS digunakan oleh siswa dijelaskan pada perkembangan sosio-emosional anak sesuai indikator umur 7-8 tahun bahwa anak memiliki pemahaman sosial yang lebih luas dan dapat merasa terganggu dengan program pemberitaan yang menampilkan kekerasan. Hal ini terlihat bagaimana bentuk kepedulian siswa dengan sesama teman sebayanya ketika teman satu kelas sakit dan mengantarkannya ke ruang $\mathrm{UKS}$.

Terakhir adalah kesehatan. Kesehatan sangat penting untuk diperhatikan sekolah. Hal ini terbukti SD Negeri Ngupasan Yogyakarta memiliki "Kantin Sehat". Kantin ini sangat selektif dalam menjual makanan, apalagi makanan yang disinyalir mengandung boraks dan formalin. Kantin sehat ini diawasi oleh seluruh warga sekolah, khususnya kepala sekolah, agar makanan yang dijual merupakan makanan yang bersih dan sehat.

\section{Partisipasi Anak}

Indikator SRA menyebutkan untuk melibatkan siswa dalam proses penyusunan Rencana Kerja Anggaran Sekolah (RKAS), menyusun tata tertib, sekolah, dan lain sebagainya. Harapan adanya partisipasi siswa dalam Sekolah Ramah Anak agar lingkungan sekolah lebih transparan dan ramah untuk anak dan semua civitas akademika sekolah. Di SD Negeri Ngupasan Yogyakarta, siswa belum dilibatkan dalam kegiatan itu, karena hal tersebut cukup diwakilkan kepada orang tua siswa, tetapi siswa tetap dapat berpartisipasi, sehingga pihak sekolah mengalihkannya ke dalam kegiatan lain, seperti melibatkan dalam hal penataan kelas, menata ruang perpustakaan, dan bekerja bakti di sekolah. Partisipasi siswa juga terlihat terlibat dalam kegiatan-kegiatan ektrakurikuler, kelas inspirasi, dan kegiatan sekolah lainnya.

Perkembangan sosio-emosional anak pada indikator umur 7-8 tahun bahwa anak dapat bersahabat dan bekerjasama dan indikator umur 8-9 tahun bahwa 
anak cenderung mampu bekerjasama serta suka ketika diberikan tanggung jawab. Pada indikator ini, anak kelas rendah sampai kelas tinggi lebih menyukai diberi tanggung jawab, seperti kegiatan penataan kelas yang dibimbing wali kelas bersama siswa untuk mengatur tempat duduk yang mana setiap minggunya posisi tempat duduk selalu berubah-ubah.

Bentuk partisipasi lainnya adalah ketika adanya kerja bakti di sekolah. Semua siswa sangat antusias dengan kegiatan tersebut. Hal ini sesuai dengan penjelasan dari Carolyn Meggitt dalam upaya meningkatkan perkembangan sosioemosional anak dalam konteks "memberikan anak lebih tanggung jawab". Guru memberikan anak sebuah dukungan dan semangat. Hal ini selaras dengan peran Sekolah Ramah Anak dalam indikator SRA menyebutkan untuk melibatkan siswa dalam proses penyusunan Rencana Kerja Anggaran Sekolah (RKAS), menyusun tata tertib, sekolah dan lain sebagainya. Walaupun sebagian kegiatan tersebut diwakilkan oleh orang tua, tetapi siswa diberikan keleluasaan untuk berpartisipasi dalam setiap kegiatan lain yang menunjang RKAS tersebut.

\section{Partisipasi Orang Tua}

Secara konsep, suksesnya suatu program tidak terlepas dari peran semua pihak yang ada di sekitarnya. Begitu juga keberhasilan menyelenggarakan Sekolah Ramah Anak perlu kerjasama dengan banyak pihak tak terkecuali orang tua siswa. Di sekolah ini, nama untuk perkumpulan orang tua siswa disebut sebagai paguyuban. Paguyuban terdiri dari semua kelas dari kelas 1 sampai kelas 6. Paguyuban orang tua siswa yang telah terbentuk di SD Negeri Ngupasan Yogyakarta memberikan peran yang besar terhadap kerja sama pihak sekolah dengan orang tua siswa. Paguyuban ini juga bisa disebut dengan Parenting and Gathering. Dengan adanya ini, diharapkan dapat menumbuhkan rasa kekeluargaan antara warga sekolah dengan orang tua suswa (Ichsan, 2018:78). Paguyuban ini dimanfaatkan oleh pihak sekolah untuk mensosialisasikan Sekolah Ramah Anak (SRA) dan Adiwiyata sebagai program sekolah unggulan. Komunikasi semakin terjalin baik antara sekolah dan orang tua melalui media sosial seperti group WhatsApp.

Sosialisasi yang dilakukan sekolah kepada orang tua di antaranya adalah memberikan waktu bermain anak agar tidak mengekang dan mengambil hak bermain anak dengan kegiatan di luar sekolah seperti bimbingan belajar privat atau kelompok. Sesuai pada perkembangan sosio-emosional anak usia dasar dalam indikator umur 11-12 tahun bahwa anak lebih memilih untuk menghabiskan waktu bersama temannya dan anak pada indikator umur ini cenderung lebih suka berteman dengan teman yang bergender sama.

SD Negeri Ngupasan Yogyakarta sebagai penyelenggara Sekolah Ramah Anak juga melibatkan partisipasi aktif orang tua dalam memenuhi hak siswa. Hal ini seperti orang tua memberikan waktu rutin sekurang-kurangnya 20 menit dalam sehari untuk menanggapi curahan hati (curhat) anak. Hal ini sesuai dengan 
penjelasan Carolyn Meggitt dalam upaya meningkatkan perkembangan sosioemosional anak dalam konteks "menjaga hubungan yang hangat dan terbuka dengan anak" dan "meluangkan waktu bersama sebagai keluarga". Indikator perkembangan sosio-emosional anak usia dasar bahwa siswa telah mengembangkan kemampuan untuk mengatur emosi sendiri dan indikator umur 11-12 tahun bahwa anak jauh lebih mampu mengekspresikan atau menahan emosi. Hal ini tidak terlepas dari peran orang tua yang memberikan waktunya untuk mendengarkan cerita dari anak sehingga apa yang dipikirkan oleh anak tidak menjadi beban atau pikiran yang terpendam yang akan berdampak buruk kepada perkembangan sosio-emosionalnya.

Banyaknya ekstrakurikuler dan kegiatan terkait SRA yang ada di SD Negeri Ngupasan Yogyakarta harus disertai dengan dukungan oleh orang tua dalam mengembangkan minat dan bakat siswa di sekolah. Selain Orang tua siswa memperhatikan tumbuh kembang minat dan bakat anak, mereka juga sangat peduli terhadap keamanan dan keselamatan anaknya. Orang tua siswa di SD Negeri Ngupasan Yogyakarta biasa mengantar anak-anaknya ke sekolah karena alasan jauh dan demi keamanan.

Paguyuban pernah mengadakan studi tour di alun-alun Yogyakarta secara rutin dalam rangka meningkatkan pengetahuan siswa tentang budaya di sekitarnya. Hal ini untuk mengenalkan kepada siswa tentang budaya lokal dan kearifal lokal di daerahnya tersebut. Hal ini sesuai dengan penjelasan Carolyn Meggitt adanya upaya untuk meningkatkan perkembangan sosio-emosional anak, yaitu membantu anak menjelajahi dunianya, khususnya kelas rendah. Terbentuknya paguyuban dan kerjasama yang baik antara orang tua dengan pihak sekolah, maka sekolah dapat mengadakan perjalanan ke museum dan ke tempat-tempat budaya lainnya sebagai bentuk partisipasi kepada siswa untuk dapat menjelajahi dunia siswa. Anak dapat berinteraksi dari program tersebut secara langsung dengan lingkungan sekitar dan dapat mempelajari budayanya dengan baik dan antusias.

Beberapa penjelasan di atas, di sini peneliti akan menjelaskan kesimpulan hasil penelitian sebagaimana tabel 1 di bawah ini: 
Tabel 1. Implementasi program sekolah ramah anak dalam pengembangan sosioemosional anak di SD Negeri Ngupasan Yogyakarta

\begin{tabular}{|c|c|}
\hline $\begin{array}{l}\text { Implementasi Program SRA di SD } \\
\text { Negeri Ngupasan Yogyakarta }\end{array}$ & $\begin{array}{l}\text { Percapaian Perkembangan Sosio- } \\
\text { Emosional Anak }\end{array}$ \\
\hline $\begin{array}{l}\text { 1. Kebijakan Sekolah Ramah } \\
\text { Anak } \\
\text { a. Pendidikan anti-kekerasan } \\
\text { b. Menjunjung tinggi hak anak } \\
\text { disabilitas } \\
\text { c. Kawasan sekolah tanpa } \\
\text { rokok } \\
\text { d. Sekolah aman dari bencana }\end{array}$ & $\begin{array}{l}\text { 1. Menghargai orang lain } \\
\text { 2. Mengontrol perasaan, tanggung } \\
\text { jawab, suka membantu } \\
\text { 3. Argumentatif, suka mengatur, dan } \\
\text { responsif } \\
\text { 4. Menanggapi penjelasan dengan positif } \\
\text { 5. Mengontrol emosi } \\
\text { 6. Mengekspresikan dan menahan emosi } \\
\text { 7. Terikat pada figur orang tua } \\
\text { 8. Pemahaman sosial yang lebih luas } \\
\text { 9. Cenderung mampu bekerjasama dan } \\
\text { suka ketika diberi tanggung jawab }\end{array}$ \\
\hline $\begin{array}{l}\text { 2. Pelaksanaan Kurikulum } \\
\text { a. RPP terintegrasi hak anak } \\
\text { b. Jadwal guru menyambut } \\
\text { siswa pagi hari } \\
\text { c. Ruang kelas yang bersih dan } \\
\text { luas serta mempunyai media } \\
\text { pembelajaran } \\
\text { d. Memiliki alat permainan } \\
\text { e. Berbagai macam } \\
\text { ekstrakurikuler } \\
\text { f. Menyelanggaraan kelas } \\
\text { inspirasi dan kreatif }\end{array}$ & $\begin{array}{l}\text { 1. Anak dapat memainkan permainan } \\
\text { yang memakai aturan } \\
\text { 2. Menikmati bermain maupun } \\
\text { menciptakan permainan sendiri dan } \\
\text { cenderung berteman dengan teman } \\
\text { berjenis sama atau berlandaskan } \\
\text { kesamaan hobi } \\
\text { 3. Anak bangga terhadap kompetensi } \\
\text { diri sendiri, mudah patah semangat, } \\
\text { mulai mengidentifikasi aktivitas, dan } \\
\text { kemampuan tertentu sebagai } \\
\text { karakter yang maskulin dan feminim } \\
\text { 4. Dapat mengikuti kejadian dari awal } \\
\text { hingga akhir. }\end{array}$ \\
\hline $\begin{array}{l}\text { 3. } \\
\text { Pendidik dan tenaga } \\
\text { kependidikan terlatih hak-hak } \\
\text { anak dan pendidikan } \\
\text { pengurangan resiko bencana }\end{array}$ & $\begin{array}{l}\text { 1. Anak dapat memahami dan } \\
\text { menyadari hak-haknya dalam ruang } \\
\text { pendidikan } \\
\text { 2. Menciptakan suasana kondusif dan } \\
\text { kesadaran yang lebih tinggi warga } \\
\text { sekolah terkait hak-hak anak } \\
\text { 3. Pemahaman sosial dari warga sekolah } \\
\text { secar luas, sehingga dapat mengurasi }\end{array}$ \\
\hline
\end{tabular}


DOI: $110.35329 /$ fkip.v17il.1810

\begin{tabular}{|c|c|}
\hline & resiko apapun. \\
\hline $\begin{array}{l}\text { 4. Sarana dan Prasarana Sekolah } \\
\text { Ramah Anak } \\
\text { a. Tulisan dinding mengajak } \\
\text { tidak membully } \\
\text { b. Memiliki kapasitas ruangan } \\
\text { sesuai jumlah anak dan } \\
\text { memiliki sarana prasarana } \\
\text { kelas LCD, CCTV dan kipas } \\
\text { angin, } \\
\text { c. Toilet dan kamar mandi } \\
\text { terpisah } \\
\text { d. Tempat sampah terpilah } \\
\text { e. Tempat cuci tangan } \\
\text { f. Tempat ibadah untuk tiga } \\
\text { pemeluk agama bagi siswa } \\
\text { g. Ruang UKS } \\
\text { h. Memiliki kantin sehat. }\end{array}$ & $\begin{array}{l}\text { 1. Menginternalisasi aturan sosial dalam } \\
\text { budayanya } \\
\text { 2. Dapat memainkan permainan yang } \\
\text { memakai aturan } \\
\text { 3. Memiliki sifat nilai toleransi } \\
\text { 4. Pemahaman sosial luas }\end{array}$ \\
\hline 5. $\quad$ Partisipasi Siswa & $\begin{array}{l}\text { 1. Dapat bersahabat dan bekerjasama } \\
\text { 2. Kerjasama dan suka diberi tanggung } \\
\text { jawab }\end{array}$ \\
\hline $\begin{array}{l}\text { 6. Partisipasi Orang Tua } \\
\text { a. Paguyuban orang tua siswa } \\
\text { b. memberikan waktu bermain } \\
\text { anak } \\
\text { c. Memiliki waktu untuk } \\
\text { mendengarkan curhat anak } \\
\text { d. Peduli keamanan dan } \\
\text { kenyamanan } \\
\text { e. Mengadakan study tour }\end{array}$ & $\begin{array}{l}\text { 1. Anak lebih memilih menghabiskan } \\
\text { waktu bersama teman dan cenderung } \\
\text { berteman dengan bergender sama } \\
\text { 2. Mengatur emosi dan lebih dapat } \\
\text { mengekspresikan emosi }\end{array}$ \\
\hline
\end{tabular}

\section{SIMPULAN}

Implementasi Sekolah Ramah Anak (SRA) di SD Negeri Ngupasan Yogyakarta telah berjalan dengan baik dengan tahap pelaksanaannya meliputi berbagai kebijakan yang sesuai yang diharapkan. Kontribusi yang didapatkan dari implementasi Program Sekolah Ramah Anak dalam pengembangan sosioemosional anak usia dasar adalah siswa di SD Negeri Ngupasan Yogyakarta lebih dapat menghargai orang lain, lebih bisa mengontrol emosi, responsif serta murah hati, menanggapi dengan positif, terikat pada figur orang tua, lebih peduli sosial, keinginan untuk meniru temannya, dapat memainkan permainan yang memakai 
aturan dan menciptakan permainan sendiri, sampai anak lebih suka bekerjasama dan bertanggung jawab atas apa yang telah dilakukannya.

\section{DAFTAR PUSTAKA}

Ambarsari, Luthfiana \&. Harun. 2018. "Sekolah Ramah Anak Berbasis Hak Anak di Sekolah Dasar." Profesi Pendidikan Dasar 5(1).

Alfina, A. dkk. "Manajemen Sekolah Ramah Anak PAUD Inklusi." Al-Tanzim: Jurnal Manajemen Pendidikan Islam 4(01).

Anon. 2014. "Peraturan Menteri Negara Pemberdayaan Perempuan dan Perlindungan Anak Republik Indonesia Nomor 8 Tahun 2014 Pasal 1 Ayat 3."

Barseli, Mufadhal, dkk. 2017. "Konsep Stres Akademik Siswa." Jurnal Konseling dan Pendidikan 5(3).

Carter, Debora. 2016. “A Nature-Based Social-Emotional Approach to Supporting Young Children's Holistic Development in Classrooms With and Without Walls: The Social-Emotional and Environmental Education Development (SEED) Framework." International Journal of Early Childhood Environmental Education.

Chrislando, Afan. 2019. “Vol. 15, No. 1, Mei 2019." Pepatudzu: Media Pendidikan Dan Sosial Kemasyarakatan 15(1):1-7.

Desmita. 2010. Psikologi Perkembangan Siswa. Bandung: Rosdakarya.

Hasibuan, Ahmad Tarmizi \&. Rahmawati. 2019. "Sekolah Ramah Anak Era Revolusi Industri 4.0 di SD Muhammadiyah Pajangan 2 Berbah Yogyakarta." Al-Bidayah: Jurnal Pendidikan Dasar Islam 11(1).

Humaidi, Asrorun Ni'am Sholeh \&. Lutfi. 2016. Panduan Sekolah \& Madrasah Ramah Anak. Jakarta: Erlangga.

Hurlock, Elizabeth B. 1987. Perkembangan Anak. Jakarta: Erlangga.

Ichsan, Ahmad Shofiyuddin. 2018. "Gerakan Literasi Sekolah di Sekolah Islam (Sebuah Analisis Implementasi GLS di MI Muhammadiyah Gunungkidul)." Al-Bidayah: Jurnal Pendidikan Dasar Islam 10(01).

Ichsan, Ahmad Shofiyuddin. 2019. “"Maniak' Media Sosial dan Game pada Anak Usia Dasar (Studi pada Siswa Madrasah Ibtidaiyah Yogyakarta)." Magistra: Media Pengembangan Ilmu Pendidikan Dasar Dan Keislaman 10(01):1-25.

Karmila, Kristanto; Ismatul Khasanah; Mila. 2011. "Identifikasi Model Sekolah Ramah Anak (SRA) Jenjang Satuan Pendidikan Anak Usia Dini SeKecamatan Semarang." Jurnal Penelitian PAUDIA 1(1).

Meggitt, Carolyn. 2012. Memahami Perkembangan Anak. Jakarta: Indeks.

Nuraeni, L. dkk. "Efektivitas Program Sekolah Ramah Anak dalam Meningkatkan Karakter Anak Usia Dini." Jurnal Obsesi: Jurnal Pendidikan Anak Usia Dini 4(1).

Soetjiningsih, Cristiana Hari. 2014. Perkembangan Anak. Jakarta: Prenada. 
Sugiyono. 2017. Metode Penelitian Kualitatif Untuk Penelitian Yang Bersifat: Eksploratif Interaktif Dan Konstruktif. Bandung: Alfabeta.

Sukmadinata, Nana Syaodih. 2015. Metode Penelitian Pendidikan. Bandung: Remaja Rosdakarya.

Suryadi, Ace. 2002. Pendidikan, Investasi SDM, Dan Pembangunan. Jakarta: Balai Pustaka.

Yosada, KR. \& Kurniati, A. "Menciptakan Sekolah Ramah Anak" Jurnal Pendidikan Dasar Perkhasa 5(2). 